\title{
A More Comprehensive Reform Is Needed to Ensure That Mobile Citizens Can Vote
}

\author{
Sue Collard
}

This initiative is a timely exercise with the upcoming prospect of the European Year of Citizens in 2013, and it has stimulated an interesting and useful debate in which the various contributions have covered most of the key issues at stake in the proposal. There are however a few questions that I would like to raise to add to the discussion.

The first concerns the definitions of residence and mobility: it seems to me that all the contributors have assumed that intra-EU migration is pretty much limited to the movement of citizens from one Member-State to another where they establish residence and then remain there, hence the apparent suitability of Bauböck's proposal of the acquisition of dual nationality as being the optimum scenario for this category of individuals. Yet the reality of mobility for a growing number of EU citizens, especially younger adults, is more fluid and complex than this, often involving a chain of moves from one country to another, with more or less extended periods of residence according to circumstances. I am thinking for example of a German friend, who has lived in the UK for ten years, having lived previously in Spain and France for six years each. How would any of David Owen's options cater for this kind of situation? And what of the young student, already having dual nationality through his/her parents, who decides to settle after a successful Erasmus experience in a third EU country: should he/she be allowed to take a third (or more) nationality? As regards the definition of residence, here too, with the growth of lifestyle migration, the concept has become much more fluid: the circumstances of some of the British residents in France that I interviewed revealed in many cases a highly complex residential status and there was significant evidence of what Groenendijk refers to as 'hiding their migration', either from the host country or that of their nationality, usually for reasons relating to health care or tax issues. How should residence be defined and proven? Fiscal registration? Electoral registration? Medical registration? There is currently no minimum requirement in terms of length of residence for registration for local elections, but for national elections, the five year period would seem to be reasonable; however, ex-pats who typically work to five year contracts, often moving from one country to 
another, would be constantly going back to square one. The idea of voting rights based on residence is less straightforward than it might appear.

My second question relates to the situation of EU citizens who migrate to non-EU countries of which they are not nationals: if national voting rights were guaranteed for EU citizens resident in other Member-States on the grounds that they should not be disenfranchised, would it then be acceptable for other EU citizens to lose their voting rights if they choose to migrate to a non-EU country, such as British citizens settling in the USA? Would this be their punishment for leaving the haven of the EU?

My third question is about third country nationals (TCNs), who are far more numerous than second country nationals (SCNs), as Wilhelm has pointed out: several contributors have made the point that legislation at EU level would be impossible, and that the diversity of Member-States' political and historical circumstances should in any case be respected, yet clearly the link between these two categories of migrants is fundamental to the EU's perception of itself as inclusive or exclusive. There are strong arguments in favour of giving voting rights at local elections to long term TCNs, as many Member-States already do, but this should not be at the price of increased xenophobic reactions. The dilemma is well illustrated by the French case: François Mitterrand's campaign manifesto in 1981 included a pledge to give the right to vote in local elections to all foreigners, but the opposition it aroused, articulated indirectly through the rise of the National Front, meant that this was never implemented. Indeed, France was one of the countries that for various reasons put up strongest resistance in the Maastricht debate to the voting rights enshrined in European Citizenship, but largely because many feared it would be the thin end of the wedge, opening the door to the same rights for TCNs. In spite of the electoral success of the National Front in the presidential elections, Socialist President François Hollande has indeed pledged to do just this, and we should watch closely to see if his government has the courage and political support in the new National Assembly to go through with it, in the face of claims by the mainstream Right as well as the National Front, of an implied 'drift towards communitarianism' and the spectre of Muslim-dominated local councils organising women only swimming sessions and banning all pork products from school canteens. The false premise on which this scaremongering is predicated (many Muslims already have French nationality and therefore the right to vote at all elections) is all the more unjustified when one considers the low 
rates of registration and participation in local elections by non-national EU citizens in France, estimated at under 15 per cent. Indeed, all the evidence suggests that if given the right to vote in local elections, only a small percentage of TCNs would actually use it.

Which brings us to the fourth question of the low mobilising value of voting rights, as pointed out by Wilhelm. Cayla and Seth, ask 'Who wants to go and live in a country without being able to exercise full democratic rights?', implying that few would; but the reality is surely otherwise, and it is quite clear from my own research in France and the UK that the vast majority of EU migrants do not take up their right to vote in local elections. Rodriguez's contribution suggests a similar picture in Spain, and I agree that much more could be done to increase participation at this level before moving into demands for national voting rights. Yet many of the non-national EU citizens that I interviewed, both in France and the UK, were far more concerned by the national vote than the local, and felt it impacted more on the reality of their lives: 'Why can't I vote if I pay my taxes?' was a common complaint. Long term French ex-pats at least retain their right to vote in all elections in France, whereas the British lose all voting rights in the UK after 15 years, even if they continue to pay taxes there.

So what answers can be found to all these questions and what contribution could the proposed ECI make here? Clearly, it makes a mockery of the democratic credentials of the EU if the very mobility that it seeks to encourage, brings with it political disenfranchisement. Member-States should have to recognise this, through a process of concerted action between them and EU institutions, as advocated by Shaw, by adapting their national legislations as necessary: all countries should be encouraged to allow the possibility of dual nationality, and those like the UK and Ireland operating restrictive policies towards ex-pats (at least two cases are currently being taken through the European Court of Human Rights by British ex-pats living in Spain and Italy), should be urged to update their laws in line with the first Protocol to the European Convention on Human Rights. Within this more permissive legal framework, citizens should be allowed to choose, depending on their circumstances, whether to vote in their country of residence or of nationality, thereby signifying a voluntary act of consent, and in no circumstances should any EU citizen be disenfranchised. 
How could these goals be achieved? It is clear that pressure needs to be exerted by citizens on both EU institutions and national governments to bring about the necessary changes, and in this respect the ECI has the great virtue of launching a debate, albeit so far within a very restricted circle of interested individuals. Whilst I do not think its draft objectives are sufficiently well defined or realistic to be successful as it stands, I would be prepared to sign the petition to get the ball rolling towards a wider audience.

Open Access This chapter is licensed under the terms of the Creative Commons Attribution 4.0 International License (http://creativecommons.org/licenses/by/4.0/), which permits use, sharing, adaptation, distribution and reproduction in any medium or format, as long as you give appropriate credit to the original author(s) and the source, provide a link to the Creative Commons license and indicate if changes were made.

The images or other third party material in this chapter are included in the chapter's Creative Commons license, unless indicated otherwise in a credit line to the material. If material is not included in the chapter's Creative Commons license and your intended use is not permitted by statutory regulation or exceeds the permitted use, you will need to obtain permission directly from the copyright holder. 